\title{
Molecular integrity and global gene expression of breast and lung cancer stem cells under long-term storage and recovery
}

\author{
Feridoun Karimi-Busheri • Victoria Zadorozhny • \\ Ewa Carrier · Habib Fakhrai
}

Received: 18 January 2012/ Accepted: 20 April 2012/Published online: 18 May 2012

(C) The Author(s) 2012. This article is published with open access at Springerlink.com

\begin{abstract}
Cryopreservation is a common procedure widely used in biological and clinical sciences. Similar protocols are also applied in preserving cancer stem cells, a field with high promises and challenges. Specific cell surface membrane proteins are considered to be biomarkers of cancer stem cells and they may play a critical role in differentiating stem cells from non stem cells. We have looked at the possible effect of long-term cryopreservation on the molecular integrity of breast MCF7 and lung, A549 and H460, cancer stem cells and to assess if these cells are more sensitive to long-term storage process. We analyzed the expression of CD24 and CD38 as two potent biomarkers of lung cancer stem cells and EpCAM and ALDH that are used as biomarkers of a wide range of cancer stem cells. We also selected three genes essential for the normal functioning of the cells, Fos, MUC1, and HLA. Our results indicate a pattern of down-regulation in the expression of the genes following freezing, in particular among cell surface marker proteins. Global gene
\end{abstract}

F. Karimi-Busheri $(\bowtie) \cdot$ V. Zadorozhny ·

E. Carrier · H. Fakhrai

Stem Cell Department, NovaRx Corporation, 6828 Nancy

Ridge Drive, San Diego, CA 92121, USA

e-mail: fkarimi@novarx.com

Present Address:

F. Karimi-Busheri

Department of Oncology, University of Alberta,

Edmonton, Canada

e-mail: fkarimi@ualberta.ca expression of the post-thaw breast and lung cancer stem cells also reveals a significant down-regulation in freeze-thaw cells independent from each other. Analyzing the canonical pathways between two populations reveals a significant alteration in the gene expression of the pathways involved in cell cycle, mitosis, and ataxia telangiectasia mutated pathways. Overall, our results indicate that current protocols for long-term storage of lung and breast cancer stem cells may substantially influence the activity and function of genes.

Keywords Breast cancer stem cells - Lung cancer stem cells · Mammospheres · Lungospheres ·

Biomarkers $\cdot$ Cryopreservation

\section{Introduction}

Cryopreservation has played a significant role in the advancement of modern science, in particular in biological science, since its application in mid twentieth century by James Lovelock (Mazur 1970). Despite physical and biological stresses to the cells and tissues during long term storage (Bischof et al. 2002) almost every field from basic to clinical sciences and from embryonic stem cells to regenerative medicine has benefitted greatly by cryoprotectants and cryopreservation techniques (Pegg 2002; Manipalviratn et al. 2006; Woods et al. 2004; Berz et al. 2007; Ware et al. 2005).

Cancer stem cells also known as tumor-initiating cells is an emerging field of study that has extensively 
expanded our vision on cancer development, progression and metastasis (Karimi-Busheri et al. 2010a, b; Pardal et al. 2003; Zhang and Rosen 2006; O'Brien et al. 2009; Monteiro and Fodde 2010). These cells have been isolated from almost all malignancies including hematopoietic, breast, brain, pancreas, and prostate cancer (Notta et al. 2011; Al-Hajj et al. 2003; Eyler et al. 2011; Lonardo et al. 2010; Lang et al. 2009). Cells associated to stem cells-like properties are capable of self-renewal and differentiation, and are resistant to conventional chemo- and radiation therapy (Milas and Hittelman 2009; Rich and Eyler 2008; Kasprzycka et al. 2006). Cancer stem cells have been shown to produce cytokines, chemokines, angiogenic factors (Levina et al. 2008; Hermann et al. 2007), and possess up-regulated signaling cascades essential for cancer metastasis, including hedgehog, epidermal growth factor receptor, NOTCH, and Bmi-1 (Mimeault and Batra 2010; Simeone 2008).

The application of cryopreservation techniques and the impact of freezing and thawing on these cells have been poorly investigated. Only a handful papers have directly addressed this issue (Karimi-Busheri et al. 2010a, b; Chong et al. 2009) and more investigation with proper improvements or modifications being tested and verified on cancer stem cells as a new breed of cells is needed.

Here we report an extensive study on the impact of long term storage of H460 and A549 lung and MCF7 breast cancer stem cells on the molecular integrity of the cells. We present data on the effect of freezing and thawing on biomarkers of cancer stem cells and other pathways. For the first time, to our knowledge, we also provide data on the alterations in the global gene profiling of cancer stem cells under cryopreservation environments and discuss if the changes are biologically meaningful and universal.

\section{Materials and methods}

Cell line, chemicals, and antibodies

The H460 (HTB-177) and A549 (CCL-185) lung and MCF7 (HTB-22) breast cancer cell lines were purchased from American Type Culture Collection (ATCC, Rockville, MD) and cultured in recommended ATCC media. Modified Eagle Medium/F12 (DMEM) was purchased from SAFC Biosciences
(Lenexa, KS), sodium bicarbonate sodium pyruvate were purchased from VWR (West Chester, PA), Penicillin/Streptomycin and B27 Supplement were purchased from Invitrogen (Life Technologies, Carlsbad, CA), and basic fibroblast growth factor (bFGF) was obtained from Millipore Inc. (Billerica, MA). Cancer stem cells were grown on low binding suspension flasks and plates purchased from Sarstedt Inc. (Newton, NC). CD38 phycoerythrin (PE), CD24 Alexa Flour 488, PE anti-human CD326 (EpCAM), and anti-human HLA-A,B,C antibody were obtained from BioLegend (San Diego, CA) and mouse antihuman CD227 (MUC1) FITC from BD biosciences (San Diego, CA). All other chemicals not specifically mentioned were from Sigma-Aldrich (St. Louis, MO).

Isolation and characterization of lung cancer stem cells (lungospheres)

Lungospheres grow as non-confluent cells of $\mathrm{H} 460$ and A549 lung cancer cell lines (Karimi-Busheri et al. 2010a, b). The authentication of both cell lines were validated by the amplification of short tandem repeated DNA sequences using PowerPlex 1.2 System (Promega, Madison WI) according to manufacturer instructions. Analysis of the data on Applied Biosystems ABI Prism 310 Genetic Analyzer confirmed the origin of the cell lines and perfectly matched with the parental cell lines obtained from ATCC (KarimiBusheri et al. 2012).

Suspended cells were collected from confluent parental cell lines and spun down gently at $900 \mathrm{rpm}$ for $5 \mathrm{~min}$. Pellets were gently dissociated with pipette and resuspended in a serum free media containing $20 \mathrm{ng} / \mathrm{ml} \mathrm{bFGF}, 20 \mathrm{ng} / \mathrm{ml}$ epidermal growth factor (EGF), $10 \mu \mathrm{g} / \mathrm{ml}$ insulin, and $4 \mu \mathrm{g} / \mathrm{ml}$ heparin (Leung et al. 2010). Cells were plated on low binding suspension plates with media change every 3-5 days.

Fluorescence-activated cell sorting (FACS) analysis

$\mathrm{CD} 24^{\text {low/ }-} / \mathrm{CD} 38^{+}$and $\mathrm{CD} 44^{+} / \mathrm{CD} 24^{\text {low/- }}$ expression were used as biomarkers of an enriched population of Lungospheres and mammospheres, respectively (KarimiBusheri et al. 2012; Rasouli-Nia et al. 2004). Approximately, $0.5 \times 10^{6}$ cells were mixed with FACS phosphate saline buffer (PBS) containing $2 \%$ fetal bovine serum (FBS) and $2 \mathrm{mM}$ ethylenediaminetetraacetic acid 
(EDTA). Cells were centrifuged at 1,200 rpm and the supernatant was removed and cells were re-suspended in $50 \mu \mathrm{l}$ FACS buffer containing $2.5 \mu \mathrm{l} \mathrm{CD} 24-\mathrm{PE}$ and $10 \mu \mathrm{l}$ CD38 Alexa Flour 488 antibodies. After incubation on ice/dark for 20 min cells were washed and resuspended again in the FACS buffer. Analysis was performed on an Attune Acoustic Focusing Cytometer from Applied Biosystems (Foster City, CA) flow cytometer. As negative control, isotype-matched labeled were used in all experiments.

Cryopreservation media and procedure

For cryopreservation of the cells we followed modified protocols published earlier by our laboratory (KarimiBusheri et al. 2010a, b) and protocols published on line (http://www.natureprotocols.com/2006/08/25/neural_ stem_cell_culture_neuro.php). Lungospheres were pelleted down by centrifugation at $800 \mathrm{rpm}$ and mixed in TrypLE Express (Invitrogen, Carlsbad, CA) followed by incubation for $10 \mathrm{~min}$. Cells were first mixed with the media (without Me2SO) and then passed

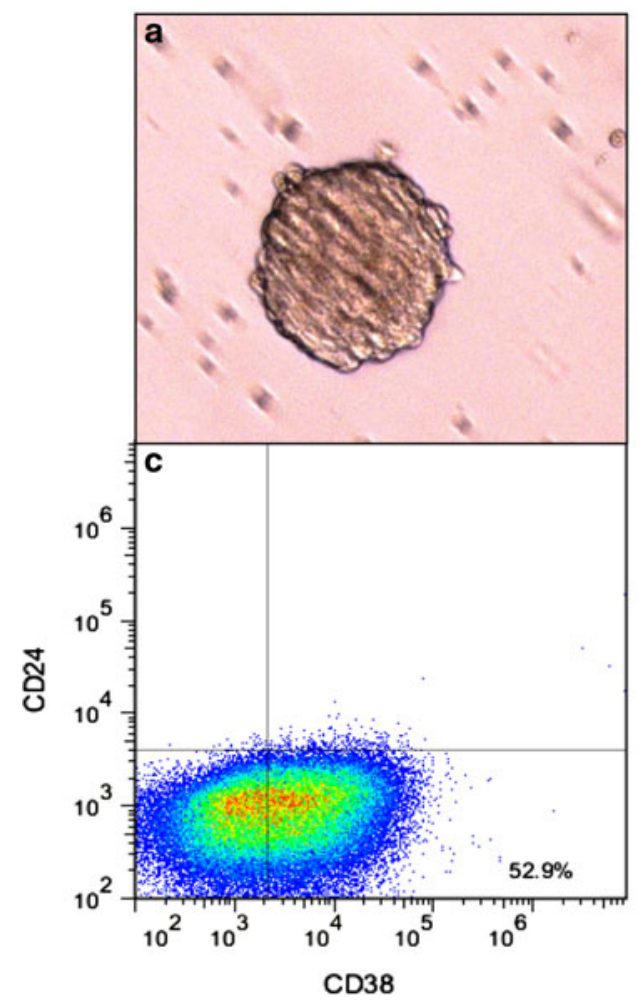

Fig. 1 Morphology and biomarkers of H460-derived lung cancer stem cells. Images of fresh (a) and two passages postthaw culture following 12 months cryopreservation of cancer through the cell strainer to remove clumps and centrifuged at $800 \mathrm{rpm}$. Supernatant were removed and cell pellets were gently mixed with cryopreservation media composed of DMEM/F12 media supplemented with non-essential amino acids, penicillin/streptomycin, 2-mercaptoethanol, B27, insulin $(5 \mu \mathrm{g} / \mathrm{ml})$, heparin $(4 \mu \mathrm{g} / \mathrm{ml}), 15 \% \mathrm{Me} 2 \mathrm{SO}$. Aliquots of $0.5 \mathrm{ml}$ of cell suspensions were transferred into cryovials and kept overnight in a $-80{ }^{\circ} \mathrm{C}$ freezer and transferred to the liquid nitrogen cryofreezer the next day for storage in vapor phase.

\section{Reestablishment of frozen lungospheres}

After 12 months, vials were removed from the liquid nitrogen and kept at room temperature to reach to ambient temperature. At this stage $10 \mathrm{ml}$ serum free media were added to the tubes followed by $5 \mathrm{~min}$ centrifuge at $800 \mathrm{rpm}$. Supernatants were removed and cells were gently mixed with lungospheres media with sterile pipettes and transferred to low binding plates and incubated at $37{ }^{\circ} \mathrm{C} / 5 \% \mathrm{CO}_{2}$. Cells were

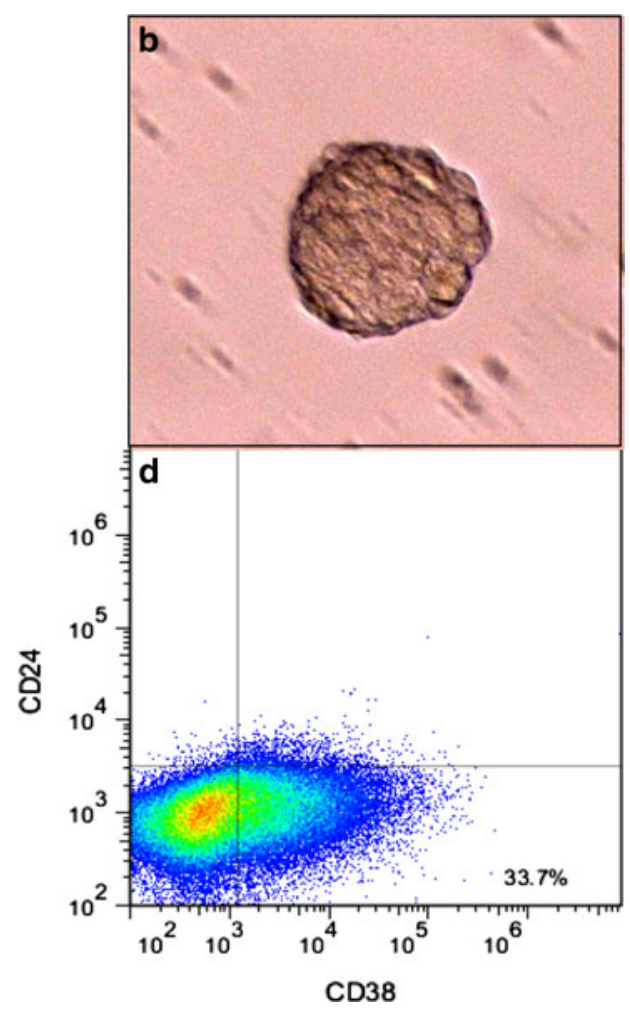

stem cells (b). CD24/CD38 expression in fresh (c) and post-thaw (d) lung cancer stem cells 
kept in culture for two passages, approximately 8 day, before being tested in different experiments.

RNA isolation and microarray analysis

Total RNA was isolated by Absolutely RNA Miniprep kit from Agilent Technologies (La Jolla, CA) from $5 \times$ $10^{6} \mathrm{H} 460$, A549, and their derived lungospheres according to the manufacturer recommendations. Quality of RNA was tested with an OD 260/280 reading of approximately 1.9 and an OD 260/230 great than 1.7 prior to send the samples for microarray analysis at the Core Facility of Sanford-Burnham Institute at La Jolla, CA. Samples were analyzed on an Ilumina Human HT-12 V3 Expression BeadChips and the data were subsequently analyzed on a BeadArray Reader at The Bioinformatics Shared Resources of Sanford-Burnham Medical Research Institute at La Jolla, CA. A $P$ value of $<0.05$ was used as a cutoff to compare the intensity values. The data were finally analyzed based on the basis of $t$ tests and fold difference changes in expression level.
Statistical analysis

Statistical differences between groups were tested by two-tailed Student's $t$ test where a $P$ value of $<0.05$ or below was considered statistically significant when means of groups of observation were compared. All experiments were performed in triplicate. Statistical and pathway analysis of the microarray data were analyzed through the use of Ingenuity Pathways Analysis (Ingenuity ${ }^{\circledR}$ Systems, www.ingenuity.com). The $P$ value was calculated by Fisher's exact test to determine if there are nonrandom associations among biological function or canonical pathways of fresh versus frozen samples.

\section{Results}

Expression of lung cancer stem cells markers

No morphological differences were observed between fresh and frozen lungospheres as displayed in Figs. 1a,

Table 1 Description of molecular targets

\begin{tabular}{|c|c|c|c|}
\hline Genes & Description & Function & Refs \\
\hline $\mathrm{CD} 24$ & $\begin{array}{l}\text { Cell adhesion molecule encodes a } \\
\text { sialoglycoprotein that is } \\
\text { expressed on mature } \\
\text { granulocytes and in many B cells }\end{array}$ & $\begin{array}{l}\text { Modulates B-cell activation } \\
\text { responses }\end{array}$ & Suzuki et al. (2001) \\
\hline $\begin{array}{l}\text { CD38 (cyclic ADP } \\
\text { ribose hydrolase) }\end{array}$ & $\begin{array}{l}\text { Marker of cell activation; novel } \\
\text { multifunctional ectoenzyme } \\
\text { widely expressed in cells and } \\
\text { tissues }\end{array}$ & $\begin{array}{l}\text { Cell adhesion, signal transduction } \\
\text { and calcium signaling }\end{array}$ & $\begin{array}{l}\text { Malavasi et al. (2008); } \\
\text { Zocchi et al. (1999) }\end{array}$ \\
\hline ALDH & Catalyze the oxidation of aldehyde & $\begin{array}{l}\text { Play a role in the metabolism } \\
\text { of many molecules }\end{array}$ & Alison et al. (2010) \\
\hline EpCAM (CD326) & $\begin{array}{l}\text { Cell surface; carcinoma-associated } \\
\text { antigen }\end{array}$ & Epithelial cell adhesion molecule & $\begin{array}{l}\text { van der Gun et al. } \\
\text { (2010) }\end{array}$ \\
\hline MUC1 (CD227) & $\begin{array}{l}\text { Cell surface; encodes a membrane } \\
\text { bound, glycosylated } \\
\text { phosphoprotein }\end{array}$ & $\begin{array}{l}\text { Cell-cell interactions, signaling, } \\
\text { and metastasis }\end{array}$ & Bafna et al. (2010) \\
\hline Fas (CD95) & $\begin{array}{l}\text { Cell surface; member of the TNF- } \\
\text { receptor superfamily }\end{array}$ & $\begin{array}{l}\text { Play a central role in the } \\
\text { physiological regulation } \\
\text { of programmed cell death. } \\
\text { Apoptosis, tumor development, } \\
\text { and progression }\end{array}$ & $\begin{array}{l}\text { Gordon and Kleinerman } \\
\text { (2009) }\end{array}$ \\
\hline HLA-A,B,C & $\begin{array}{l}\text { Major histocompatibility complex } \\
\text { (MHC) molecules cell-surface } \\
\text { receptors }\end{array}$ & $\begin{array}{l}\text { Play a central role in the immune } \\
\text { system }\end{array}$ & Charron (2011) \\
\hline
\end{tabular}

Summary and function of the genes analyzed for the impact of long-term storage (12 months) on H460- and A549-derived lung cancer stem cells 
b. We then tested two potential biomarkers of H460derived lung cancer stem cells, CD24 and CD38. Figure 1c, d represent the expression of CD24/CD38 in fresh and frozen lungospheres, respectively. Frozen lungosphere after thawing and 10 days in culture with two passages were shown to express significantly lower cell surface markers CD 24/CD38 than their freshly grown lungospheres, $p=0.003$. Table 1 summarizes the description and function of the genes studied.
Expression of ALDH and EpCAM, potent cancer stem cells markers

EpCAM expression was analyzed in both H460 lung carcinoma and A549 human lung adenocarcinoma epithelial derived lungospheres. As displayed in Fig. 2a and $\mathrm{b}$, freshly isolated and cultured lungosoheres from both cell lines exhibit a significant higher expression of EpCAM, $p=0.004$ and 0.004, respectively (Table 2). The expression of aldehyde dehydrogenase (ALDH),
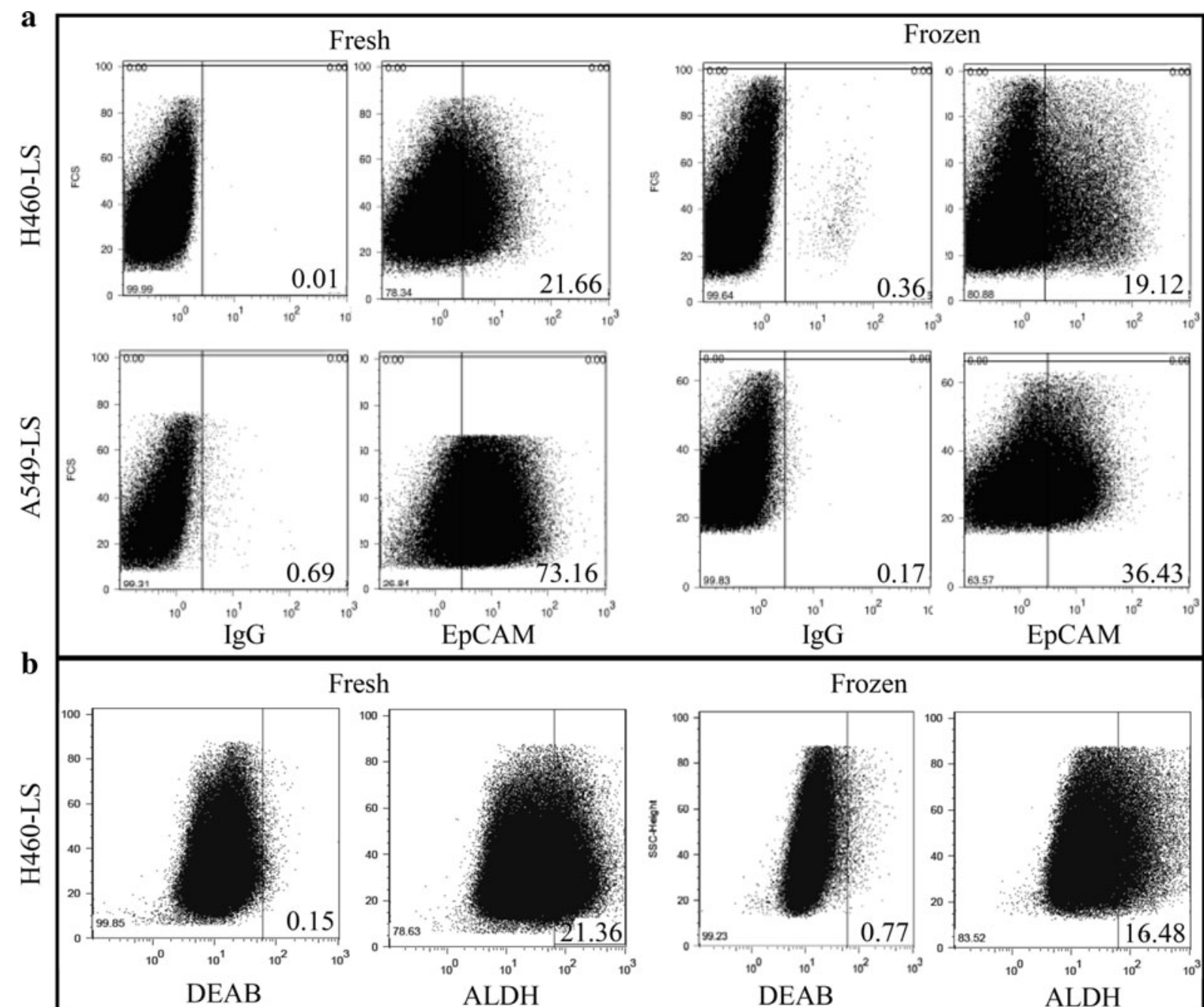

Fresh

Frozen
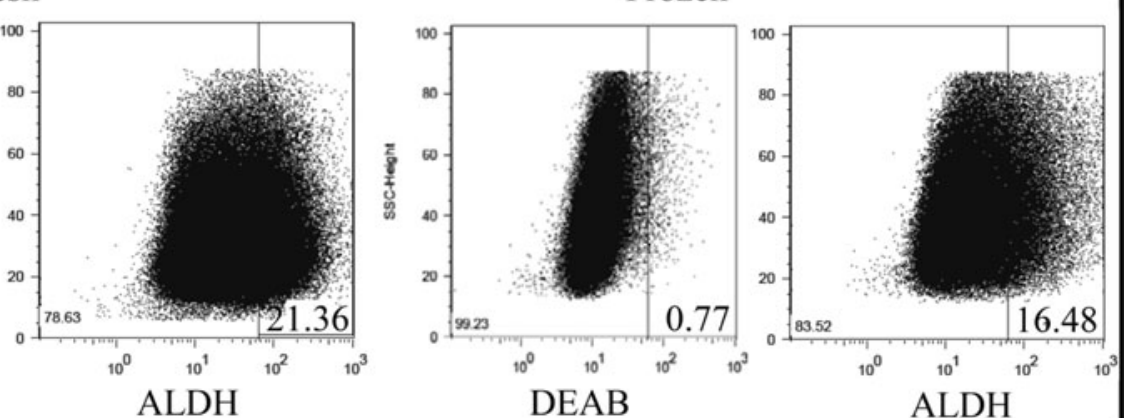

Fig. 2 Potent biomarkers of cancer stem cells activity in fresh and frozen cells. a The expression of EpCAM in H460 and A549 lungospheres (LS). IgG isotype was used as control. b Enzymatic activity of ALDH in H460-derived lungospheres in fresh and 12 months freeze-thaw cells, with DEAB, an inhibitor of ALDH as controls. c Analysis of HLA, Fas, and MUC1 by flow cytometry. Expression of three genes in H460- and A549 lungospheres are analyzed in 12 months old cryopreserved cells followed by thawing and two passages in culture and compared with freshly isolated lungospheres of both cell lines 

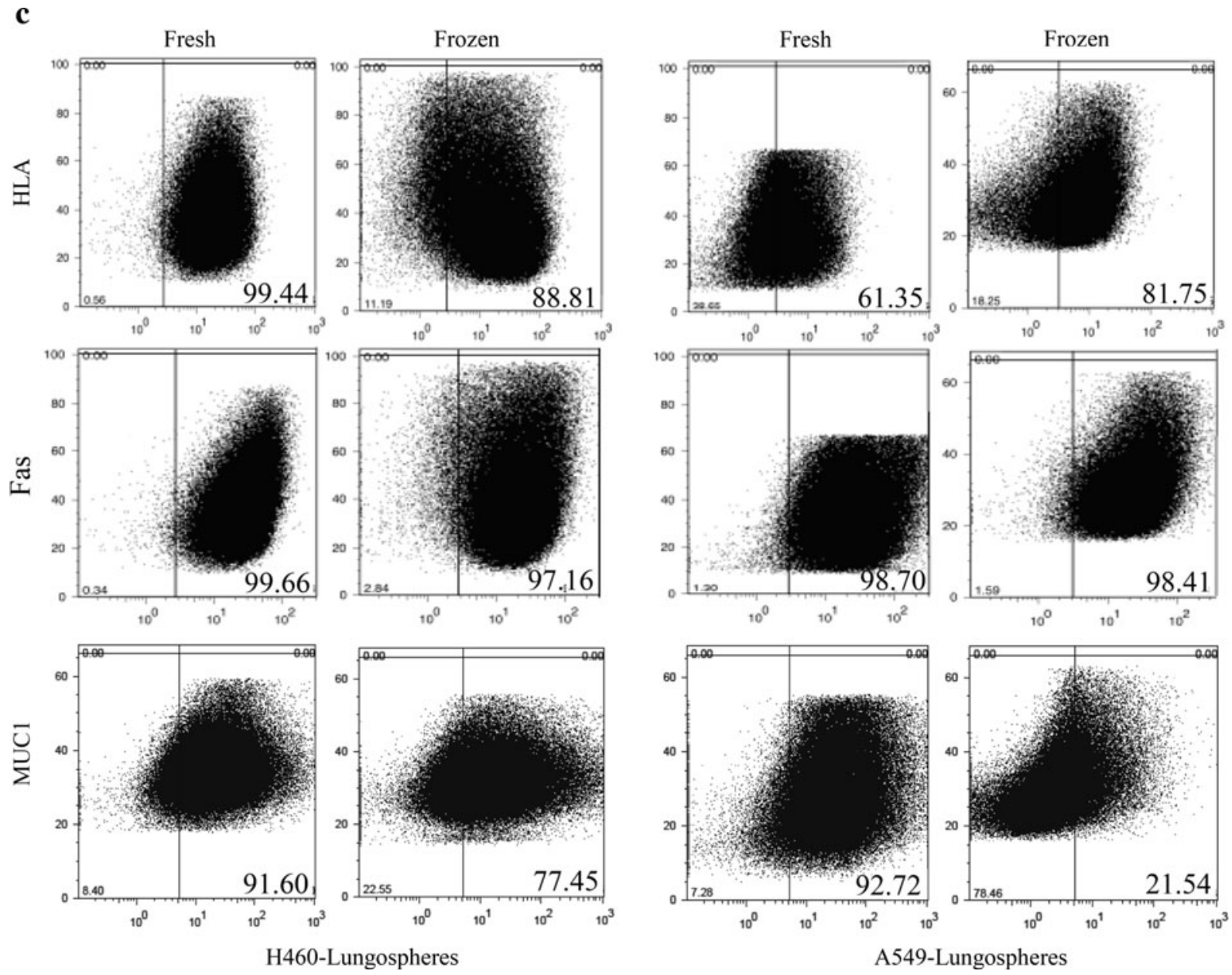

Fig. 2 continued

another potent biomarker for cancer stem cells, was only looked in H460 derived lungospheres as A549 adherent cell line express a high level of ALDH that could jeopardize the actual expression of the marker in nonadherent cells (Moreb et al. 2007). Similarly, a statistically significant, $p=0.02$, difference exists in the expression of the protein between fresh and freezethawed lungospheres as shown in Fig. 2c. Diethylaminobenzaldehyde (DEAB) a specific inhibitor of ALDH was used as control (Muramoto et al. 2010).

Expression of HLA, Fas, and MUC1

We further analyzed the impact of long term preservation on three genes essential for the normal functioning of the cells (Table 1) in H460 and A549 lung cancer stem cells (Fig. 2c). With the exception of Fas

gene, the expression of HLA and MUC1 in both cell lines are significantly different between fresh and frozen lungospheres in both cell lines. All cryopreserved cells show a lower expression of the genes than the fresh one with the exception of HLA that the postthawed cells express a higher level than the fresh one $(p=0.04)$. A summary of the results of the statistical analysis of all the genes studied are shown in Table 2 .

Microarray analysis

To test the impact of long term storage on the global gene expression of lung and breast cancer stem cells we performed a microarray analysis (Fig. 3). In lung cancer stem cells, from 636 genes that underwent a significant minimum twofold change in expression $167(26.3 \%)$ genes were up-regulated and 469 
Table 2 Statistically significant genes showing differential expression

\begin{tabular}{llll}
\hline Genes & Cell lines & $\uparrow \downarrow$ & $P$ value \\
\hline CD24/CD38 & H460-LS & $\downarrow$ & 0.004 \\
EpCAM & H460-LS & $\downarrow$ & 0.004 \\
EpCAM & A549-LS & $\downarrow$ & 0.02 \\
ALDH & H460-LS & $\downarrow$ & 0.02 \\
HLA & H460-LS & $\downarrow$ & 0.03 \\
HLA & A549-LS & $\uparrow$ & 0.04 \\
Fas & H460-LS & $=$ & 0.39 \\
Fas & A549-LS & $=$ & 0.44 \\
MUC1 & H460-LS & $\downarrow$ & 0.05 \\
MUC1 & A549-LS & $\downarrow$ & 0.0002 \\
\hline
\end{tabular}

The $P$ values for seven statistically significant up $(\uparrow)$ and down regulated $(\downarrow)$ genes in post-thaw lung cancer stem cells as compared to fresh cell \pm standard deviation of three repeats. No significant changes were observed in Fas gene between fresh and frozen cells as displayed by $=$ in the table. LS represent lungospheres

(73.7\%) genes downregulated. A significantly lower number of genes in breast cancer stem cells were affected under cryopreservation. From a total of 236 genes, $86(36.4 \%)$ were up-regulated and 150 $(63.6 \%)$ down regulated. This indicates that cryopreservation results in approximately $63 \%$ more significant changes in gene expression among lungderived cancer stem cells than breast MCF7-derived stem cells. The top tenfold change up- and downregulated molecules are displayed in Table 3.

Ingenuity pathways analysis: top biological functions

Through Ingenuity pathway analysis we looked at the statistically significant differences between fresh and prolonged cryopreserved samples of lungospheres and breast cancer stem cells (mammospheres). Various pathways and disorders were analyzed including: diseases and disorders, molecular and cellular function, physiological system development and function, and canonical pathways (Table 4A). The highest number of molecules affected by cryopreservation in both lung and breast cancer stem cells are the molecules involved in genetic diseases; 120 molecules $(38.8 \%)$ in mammospheres and 522 molecules $(36.9 \%)$ in lungospheres. Within molecular and cellular function, cryopreservation altered gene expression of 76 molecules $(25.9 \%)$ in mammospheres and 312 molecules $(28.0 \%)$ in lungospheres. When looking at the physiological system development and function we observed 45 molecules $(34.9 \%)$ involved in tissue development of mammospheres and $113(33.2 \%)$ molecules in tissue morphology function of lungospheres with significant up- or down-regulation following long term cryopreservation.

The highest ranked canonical pathways significantly affected by prolonged cryopreservation are displayed in Table 4B. None of the pathways are shared among mammospheres and lungosphere. In mammospheres, metabolism of xenobiotics by cytochrome $\mathrm{P} 450$ with a $P$ value of $3.39 \mathrm{E}-07$ and a ratio of $5.2 \%$ (11 genes out of a 213 total number of molecules that exist in this canonical pathway) represents the most altered canonical pathway. For the lungospheres mitotic roles of polo-like kinase, ataxia telangiectasia mutated (ATM) signaling, and antigen presentation represent the highest number of genes affected in the canonical pathways as displayed in Table 4B.

\section{Conclusion}

We previously discussed the impact of prolonging cryopreservation of breast cancer stem cells on the biological functioning of the cells (Karimi-Busheri et al. 2010a, b). In that report we showed that cryopreservation of breast cancer stem cells does not influence viability, proliferation, basic DNA repair ability, and self-renewal. The only difference we observed was the presence of a significantly higher number of mammospheres undergoing senescence. In this study we focused on the impact of prolonged storage on the molecular integrity and global gene expression patterns of breast and lung cancer stem cells.

Contrary to our previous findings (Karimi-Busheri et al. 2010a, b) that cryopreservation will not generate any observable changes in biological activity of the cells, including proliferation and self-renewal, here we report significant alterations at the molecular level of the post-thawed cells. To prevent the onset of senescence associated with long term culture (Kuilman et al. 2010) and adaptation to culture conditions, post-thawed cells were in culture for two passages before being analyzed. Furthermore, to increase assay 


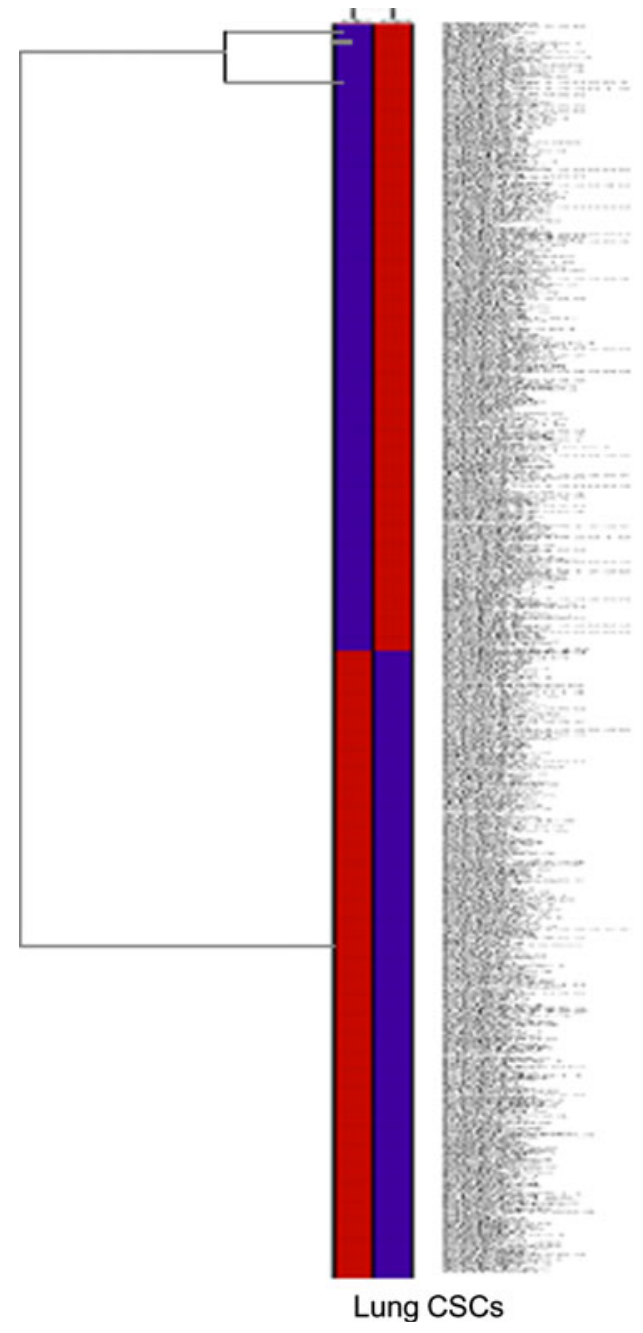

Fig. 3 Microarray analysis. RNA microarray analysis of MCF7 and H460-derived stem cells between fresh and cryopreserved post-thawed cells. The heatmaps representing the data from 4

reproducibility all the assays and equipments used in our laboratories, in particular our Attune Acoustic Focusing Cytometer from Applied Biosystems (Foster City, CA), are routinely calibrated to the FDA standard of quality to produce consistent results as a requirement for an ongoing lung cancer Phase III clinical trial of belagenpumatucel-L (Lucanix(r)) in our company. Down-regulation of the expression of seven out of nine genes following 12 months freezing could be considered as a dominant pattern in lungospheres following cryopreservation.

As the cell surface proteins play a major role in stem cell fate the majority of genes selected for this study, with the exception of ALDHA1 and HLA, were

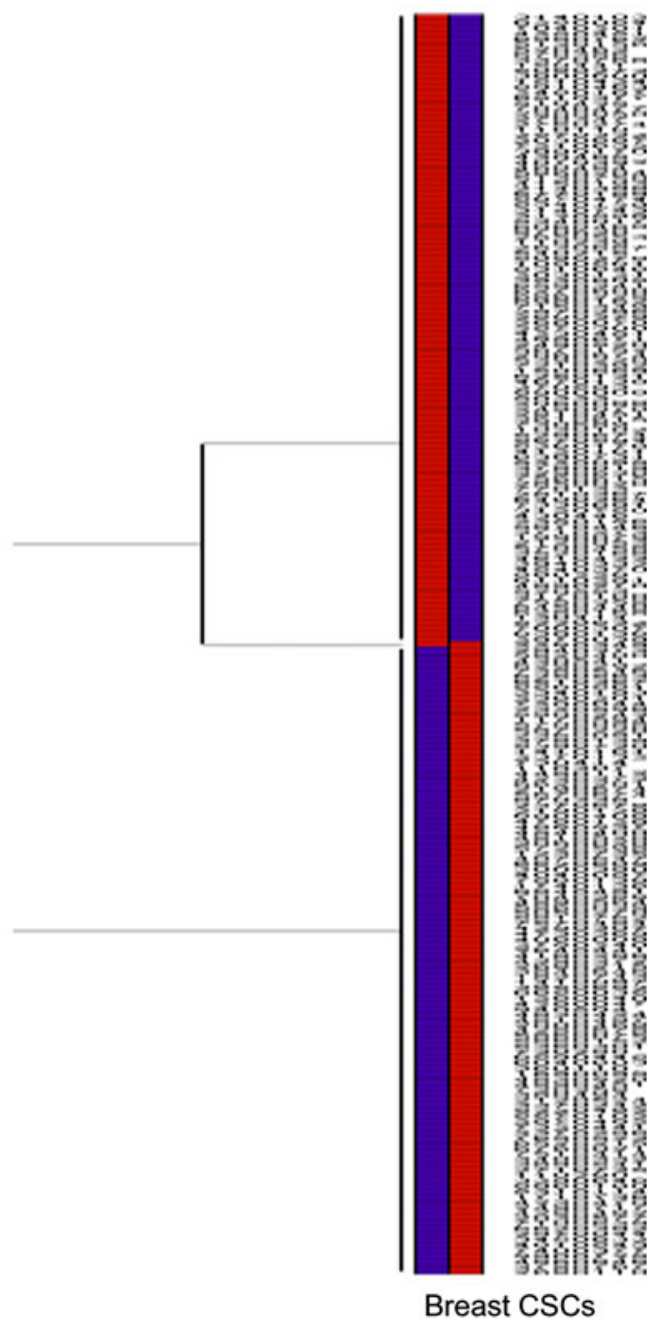

individual arrays from the twofold significant differences between fresh and cryopreserved post-thawed samples of H460- and MCF7-derived cancer stem cells

cell surface markers. As all the cell surface genes studied were down-regulated that might indicate the expected susceptibility of the stem cell membrane to cryopreservation. Previous reports have mainly focused on cell viability but a few reports, including the influence of cryopreservation on amniotic fluidderived stem cells and human limbal epithelial stem cells (Seo et al. 2011; Vasania et al. 2011) also confirm alterations in molecular profiling of stem cells. Of considerable interest is the result that the cryopreserved human limbal epithelial stem cells express negative immunoregulatory molecules and are nonimmunogenic in nature (Vasania et al. 2011). The finding clearly questions the survival of these cells in 
Table 3 Top tenfold change with highest and lowest expression

\begin{tabular}{|c|c|c|c|c|c|c|c|}
\hline \multicolumn{4}{|c|}{ Mammospheres } & \multicolumn{4}{|l|}{ Lungospheres } \\
\hline Molecule & Up & Molecule & Down & Molecule & Up & Molecule & Down \\
\hline GPX2 & 8.2 & PGM5 & 10.9 & POMC & 39.7 & TAF15 & 6.7 \\
\hline AKR1B10 & 6.4 & KLF6 & 5.8 & KRT19 & 21.3 & CHORDC1 & 4.6 \\
\hline KLK11 & 4.9 & TM4SF1 & 5.6 & GPER & 19.8 & FAM81A & 4.4 \\
\hline S100P & 4.4 & ANXA1 & 5.5 & CYR61 & 18.6 & PPP3R1 & 3.9 \\
\hline ID1 & 4.4 & KLF2 & 5.4 & CA9 & 14.4 & SLC1A3 & 3.8 \\
\hline CA2 & 3.9 & C10ORF81 & 5.2 & REG3G & 14.1 & CA2 & 3.8 \\
\hline S100A8 & 3.9 & TNFRSF11B & 4.6 & NDRG1 & 13.9 & CBX5 & 3.7 \\
\hline AKR1C3 & 3.8 & DKK1 & 4.2 & NDUFA4L2 & 13.7 & LMNB1 & 3.6 \\
\hline IFI27 & 3.7 & CYP4B1 & 4.2 & TSC22D3 & 13.2 & TAF5L & 3.6 \\
\hline AKR1C4 & 3.6 & RASD1 & 4.0 & MYOM1 & 12.6 & CCDC71 & 3.5 \\
\hline
\end{tabular}

A twofold change was set to identify molecules up- or down-regulated due to cryopreservation. The numbers under up or down represent the fold change significant differences between fresh and frozen population

an allogeneic environment. This could be a significant factor influencing the outcome of any research on stem cells that is intended to be developed for storage, good manufacturing practice, and the manufacturing of clinical grade stem cells.

Global gene expression analysis of fresh versus post-thawed breast and lung cancer stem cells also confirmed a significant amount of down regulation in freeze-thaw cells. Interestingly, gene expression changes in both cell lines are independent from each other and no one gene is shared between the two population sets. There are, however, similarities between both breast and lung cancer stem cell populations in the biological functions distribution and canonical pathways. Genes involved in genetic disorders and cancer rank the top two in the disease category affected by long term storage of the cells. Within the molecular and cellular function category, cell death and cellular growth and proliferation pathways are the most predominantly affected among the two populations. For the physiological system development and function category breast and lung stem cell populations share the highest changes in the tissue development pathway.

Analysis of canonical pathways between breast and lung cancer stem cell reveals interesting results. In post-thawed lung cancer stem cells, the majority of pathways showing significant alteration in gene expression are the pathways involved in cell cycle, mitosis, and ATM that also regulates a number of pathways involved in DNA repair, cell cycle, and apoptosis (Smith et al. 2010). In contrast, in breast cancer stem cells canonical pathways influenced by cryopreservation are mainly associated with metabolism. Our results clearly display the profound impact of long term storage of cancer stem cells under cryopreserved conditions. The influence has a wide spectrum and is cell type dependent. Down-regulation of gene expression is a dominant pattern among postthawed cells. In adherent and non-stem cell populations greater passaging after thawing could return the cells to normal but in the case of stem cells, with the possibility of senescence (Karimi-Busheri et al. 2010a, b; Kuilman et al. 2010), this could be problematic. Changing freezing conditions and reducing the amount of DMSO (Seo et al. 2011) could be an alternative that remains to be tested in different panels of tissues and cells-derived stem cells.

In conclusion, we observed direct impact of cryopreservation on the molecular integrity of cancer stem cells, in particular on the cell surface membrane. Similar results were also confirmed by global gene expression analysis on two different sets of stem cell populations all indicating a significant down regulation following long term storage of the cells. Our findings could have significant implications in the emerging field of cancer stem cells since cell surface markers, biological functional and canonical pathways play a major role towards understanding cancer initiation and progression. 
Table 4 A Distribution of top biological functions among breast and lung cancer stem cells; B top canonical pathways affected by freezing in fresh and post-thawed breast and lung cancer stem cells

\begin{tabular}{|c|c|c|c|c|c|c|c|c|}
\hline \multirow[t]{2}{*}{ Category } & \multicolumn{4}{|c|}{ Breast cancer stem cells } & \multicolumn{4}{|c|}{ Lung cancer stem cells } \\
\hline & \multicolumn{2}{|c|}{ \# Of molecules (\%) } & \multicolumn{2}{|c|}{$P$ value } & \multicolumn{2}{|c|}{ \# Of molecules (\%) } & \multicolumn{2}{|c|}{$P$ value } \\
\hline \multicolumn{9}{|l|}{ Diseases \& disorders } \\
\hline Cancer & \multicolumn{2}{|l|}{$88(28.5)$} & \multicolumn{2}{|c|}{$9.06 \mathrm{E}-13-1.13 \mathrm{E}-02$} & \multicolumn{2}{|l|}{$381(26.9)$} & \multicolumn{2}{|c|}{$1.07 \mathrm{E}-33-6.25 \mathrm{E}-04$} \\
\hline Gastrointestinal disease & \multicolumn{2}{|l|}{$32(10.4)$} & \multicolumn{2}{|c|}{$3.29 \mathrm{E}-08-2.32 \mathrm{E}-05$} & \multicolumn{2}{|l|}{$174(12.3)$} & \multicolumn{2}{|c|}{$8.87 \mathrm{E}-29-3.70 \mathrm{E}-04$} \\
\hline Reproductive system disease & \multicolumn{2}{|l|}{$56(18.1)$} & \multicolumn{2}{|c|}{$1.54 \mathrm{E}-07-9.92 \mathrm{E}-03$} & \multicolumn{2}{|l|}{$217(15.3)$} & \multicolumn{2}{|c|}{$9.64 \mathrm{E}-15-4.23 \mathrm{E}-04$} \\
\hline Genetic disorder & \multicolumn{2}{|l|}{$120(38.8)$} & \multicolumn{2}{|c|}{$1.55 \mathrm{E}-06-1.09 \mathrm{E}-02$} & \multicolumn{2}{|l|}{$522(36.9)$} & \multicolumn{2}{|c|}{$2.05 \mathrm{E}-26-4.55 \mathrm{E}-04$} \\
\hline Organismal injury \& abnormalities & \multicolumn{2}{|l|}{$13(4.2)$} & \multicolumn{2}{|c|}{$1.45 \mathrm{E}-05-6.73 \mathrm{E}-03$} & \multicolumn{2}{|l|}{-} & \multicolumn{2}{|l|}{-} \\
\hline Respiratory disease & \multicolumn{2}{|l|}{-} & - & & $121(8.6)$ & & $2.72 \mathrm{E}-$ & $-08-2.16 \mathrm{E}-04$ \\
\hline Molecular \& cellular function & & & & & & & & \\
\hline Cell death & $72(24.6)$ & & $8.89 \mathrm{I}$ & $-10-1.00 \mathrm{E}-02$ & $312(28.0)$ & & $5.95 \mathrm{E}-$ & $-23-5.73 E-04$ \\
\hline Cell cycle & 35 (11.9) & & $1.38 \mathrm{I}$ & $-05-1.06 \mathrm{E}-02$ & $174(15.6)$ & & $8.87 \mathrm{E}-$ & $-29-3.70 \mathrm{E}-04$ \\
\hline DNA replication, recomb. \& repair & & & - & & $139(12.5)$ & & $5.00 \mathrm{E}-$ & $-14-5.72 \mathrm{E}-04$ \\
\hline Cellular growth \& proliferation & $76(25.9)$ & & $2.47 \mathrm{I}$ & $-09-1.09 \mathrm{E}-02$ & $297(26.7)$ & & $2.58 \mathrm{E}-$ & $-12-4.64 \mathrm{E}-04$ \\
\hline Cellular development & $62(21.2)$ & & $1.39 \mathrm{I}$ & $-07-1.09 \mathrm{E}-02$ & - & & - & \\
\hline Cellular movement & $48(16.4)$ & & $5.02 \mathrm{H}$ & $-09-1.09 \mathrm{E}-02$ & $192(17.2)$ & & $6.74 \mathrm{E}-$ & $-12-5.72 \mathrm{E}-04$ \\
\hline Physiological system development \& ft & inction & & & & & & & \\
\hline Tissue development & $45(34.9)$ & & $2.85 \mathrm{H}$ & $-06-1.09 \mathrm{E}-02$ & $108(31.8)$ & & $1.30 \mathrm{E}-$ & $-07-5.76 \mathrm{E}-04$ \\
\hline Connective tissue development & - & & & & $69(20.3)$ & & $5.51 \mathrm{E}-$ & $-06-5.20 \mathrm{E}-04$ \\
\hline Cardiovascular system development & $29(22.5)$ & & $3.65 \mathrm{H}$ & $-06-1.09 \mathrm{E}-02$ & $40(11.8)$ & & $5.72 \mathrm{E}-$ & $-06-3.60 \mathrm{E}-04$ \\
\hline Tissue morphology & - & & & & $113(33.2)$ & & $9.34 \mathrm{E}-$ & $-06-9.40 \mathrm{E}-04$ \\
\hline Embryonic development & $27(20.9)$ & & $9.51 \mathrm{H}$ & $-05-1.07 \mathrm{E}-02$ & $10(2.9)$ & & $1.26 \mathrm{E}-$ & $-05-5.27 \mathrm{E}-04$ \\
\hline Endocrine system development & $9(7.0)$ & & $1.52 \mathrm{I}$ & $-05-9.99 \mathrm{E}-03$ & & & - & \\
\hline Organismal development & $19(14.7)$ & & $3.65 \mathrm{H}$ & $-06-9.37 \mathrm{E}-03$ & & & - & \\
\hline Breast cancer stem cells & & & & Lung cancer ster & $n$ cells & & & \\
\hline Pathway & $P$ value & Ratio ( & & Pathway & & $P$ ve & alue & Ratio (\%) \\
\hline B & & & & & & & & \\
\hline $\begin{array}{l}\text { Xenobiotics metabolism } \\
\text { by cytochrome P } 450\end{array}$ & $3.39 \mathrm{E}-07$ & $11 / 213$ & $(5.2)$ & Mitotic roles of & polo-like kinase & 1.38 & E-04 & $12 / 63(19.0)$ \\
\hline $\begin{array}{l}\text { LPS/1L-1 mediated inhibition } \\
\text { of RXR function }\end{array}$ & $1.13 \mathrm{E}-04$ & $10 / 222$ & $(4.5)$ & ATM signaling & & 1.54 & $E-04$ & $11 / 54(20.4)$ \\
\hline Fatty acid metabolism & $8.90 \mathrm{E}-04$ & $7 / 196$ & $0.4)$ & Cell cycle: $\mathrm{G} 2 / \mathrm{M}$ & & 1.63 & E-04 & $10 / 49(20.4)$ \\
\hline Galactose metabolism & $3.60 \mathrm{E}-03$ & $7 / 115$ & .4) & Protein ubiquitin & ation & 2.56 & $E-04$ & $30 / 247(10.9)$ \\
\hline Aryl hydrocarbon receptor signaling & $4.62 \mathrm{E}-03$ & $6 / 155$ & $0.4)$ & Antigen presenta & tion & 3.74 & $E-04$ & $9 / 43(20.9)$ \\
\hline
\end{tabular}

Finally, we believe current protocols for cryopreservation of cancer stem cells could substantially influence the activity and function of genes and accordingly we encourage employing rigorous research on methodology for freezing and utilizing cancer stem cells following long-term storage. These results are an alarming signals suggesting that cancer stem cells could be more sensitive to long-term storage and recovering process and part of the discrepancies in the results obtained by different investigators on biomarkers and genetic profiling of cancer stem cells might be in fact attributed to the freezing process.

Acknowledgments This work was supported by an internal grant from NovaRx Corporation. The authors are also grateful to Jason Slizgi for his technical assistance.

Open Access This article is distributed under the terms of the Creative Commons Attribution License which permits any use, 
distribution, and reproduction in any medium, provided the original author(s) and the source are credited.

\section{References}

Al-Hajj M, Wicha MS, Benito-Hernandez A, Morrison SJ, Clarke MF (2003) Prospective identification of tumorigenic breast cancer cells. Proc Natl Acad Sci USA 100:3983-3988

Alison MR, Guppy NJ, Lim SM, Nicholson LJ (2010) Finding cancer stem cells: are aldehyde dehydrogenases fit for purpose? J Pathol 222:335-344

Bafna S, Kaur S, Batra SK (2010) Membrane-bound mucins: the mechanistic basis for alterations in the growth and survival of cancer cells. Oncogene 29:2893-2904

Berz D, McCormack EM, Winer ES, Colvin GA, Quesenberry PJ (2007) Cryopreservation of hematopoietic stem cells. Am J Hematol 82:463-472

Bischof JC, Wolkers WF, Tsvetkova NM, Oliver AE, Crowe JH (2002) Lipid and protein changes due to freezing in Dunning AT-1 cells. Cryobiology 45:22-32

Charron D (2011) HLA, immunogenetics, pharmacogenetics and personalized medicine. Vox Sang 100:163-166

Chong YK, Toh TB, Zaiden N, Poonepalli A, Leong SH, Ong CE, Yu Y, Tan PB, See SJ, Ng WH, Ng I, Hande MP, Kon OL, Ang BT, Tang C (2009) Cryopreservation of neurospheres derived from human glioblastoma multiforme. Stem Cells 27:29-39

Eyler CE, Wu Q, Yan K, Macswords JM, Chandler-Militello D, Misuraca KL, Lathia JD, Forrester MT, Lee J, Stamler JS, Goldman SA, Bredel M, McLendon RE, Sloan AE, Hjelmeland AB, Rich JN (2011) Glioma stem cell proliferation and tumor growth are promoted by nitric oxide synthase-2. Cell 146:53-66

Gordon N, Kleinerman ES (2009) The role of Fas/FasL in the metastatic potential of osteosarcoma and targeting this pathway for the treatment of osteosarcoma lung metastases. Cancer Treat Res 152:497-508

Hermann PC, Huber SL, Herrler T, Aicher A, Ellwart JW, Guba M, Bruns CJ, Heeschen C (2007) Distinct populations of cancer stem cells determine tumor growth and metastatic activity in human pancreatic cancer. Cell Stem Cell $1: 313-323$

Karimi-Busheri F, Rasouli-Nia A, Mackey JR, Weinfeld M (2010a) Senescence evasion by MCF-7 human breast tumor-initiating cells. Breast Cancer Res 12:R31

Karimi-Busheri F, Zadorozhny V, Shawler DL, Fakhrai H (2010b) The stability of breast cancer progenitor cells during cryopreservation: maintenance of proliferation, self-renewal, and senescence characteristics. Cryobiology 60:308-314

Karimi-Busheri F, Zadorozhny V, Li T, Lin H, Shawler DL, Fakhrai H (2012) Pivotal role of CD38 biomarker in combination with CD24, EpCAM, and ALDH for identification of H460 derived lung cancer stem cells. Journal of Stem Cells 6:1

Kasprzycka M, Marzec M, Liu X, Zhang Q, Wasik MA (2006) Nucleophosmin/anaplastic lymphoma kinase (NPM/ALK) oncoprotein induces the $\mathrm{T}$ regulatory cell phenotype by activating STAT3. Proc Natl Acad Sci USA 103:9964-9969
Kuilman T, Michaloglou C, Mooi WJ, Peeper DS (2010) The essence of senescence. Genes Dev 24:2463-2479

Lang SH, Frame FM, Collins AT (2009) Prostate cancer stem cells. J Pathol 217:299-306

Leung EL, Fiscus RR, Tung JW, Tin VP, Cheng LC, Sihoe AD, Fink LM, Ma Y, Wong MP (2010) Non-small cell lung cancer cells expressing CD44 are enriched for stem celllike properties. PLoS ONE 5:e14062

Levina V, Marrangoni AM, DeMarco R, Gorelik E, Lokshin AE (2008) Drug-selected human lung cancer stem cells: cytokine network, tumorigenic and metastatic properties. PLoS ONE 3:e3077

Lonardo E, Hermann PC, Heeschen C (2010) Pancreatic cancer stem cells-update and future perspectives. Mol Oncol 4:431-442

Malavasi F, Deaglio S, Funaro A, Ferrero E, Horenstein AL, Ortolan E, Vaisitti T, Aydin S (2008) Evolution and function of the ADP ribosyl cyclase/CD38 gene family in physiology and pathology. Physiol Rev 88:841-886

Manipalviratn S, Huang A, Decherney AH (2006) Future of infertility treatment. Int Surg 91:S3-S14

Mazur P (1970) Cryobiology: the freezing of biological systems. Science 168:939-949

Milas L, Hittelman WN (2009) Cancer stem cells and tumor response to therapy: current problems and future prospects. Semin Radiat Oncol 19:96-105

Mimeault M, Batra SK (2010) New advances on critical implications of tumor- and metastasis-initiating cells in cancer progression, treatment resistance and disease recurrence. Histol Histopathol 25:1057-1073

Monteiro J, Fodde R (2010) Cancer stemness and metastasis: therapeutic consequences and perspectives. Eur J Cancer 46:1198-1203

Moreb JS, Zucali JR, Ostmark B, Benson NA (2007) Heterogeneity of aldehyde dehydrogenase expression in lung cancer cell lines is revealed by Aldefluor flow cytometry-based assay. Cytometry B Clin Cytom 72: 281-289

Muramoto GG, Russell JL, Safi R, Salter AB, Himburg HA, Daher P, Meadows SK, Doan P, Storms RW, Chao NJ, McDonnell DP, Chute JP (2010) Inhibition of aldehyde dehydrogenase expands hematopoietic stem cells with radioprotective capacity. Stem Cells 28:523-534

Notta F, Doulatov S, Laurenti E, Poeppl A, Jurisica I, Dick JE (2011) Isolation of single human hematopoietic stem cells capable of long-term multilineage engraftment. Science 333:218-221

O’Brien CA, Kreso A, Dick JE (2009) Cancer stem cells in solid tumors: an overview. Semin Radiat Oncol 19:71-77

Pardal R, Clarke MF, Morrison SJ (2003) Applying the principles of stem-cell biology to cancer. Nat Rev Cancer 3:895-902

Pegg DE (2002) The history and principles of cryopreservation. Semin Reprod Med 20:5-13

Rasouli-Nia A, Karimi-Busheri F, Weinfeld M (2004) Stable down-regulation of human polynucleotide kinase enhances spontaneous mutation frequency and sensitizes cells to genotoxic agents. Proc Natl Acad Sci USA 101:6905-6910

Rich JN, Eyler CE (2008) Cancer stem cells in brain tumor biology. Cold Spring Harb Symp Quant Biol 73:411-420

Seo JM, Sohn MY, Suh JS, Atala A, Yoo JJ, Shon YH (2011) Cryopreservation of amniotic fluid-derived stem cells 
using natural cryoprotectants and low concentrations of dimethylsulfoxide. Cryobiology 62:167-173

Simeone DM (2008) Pancreatic cancer stem cells: implications for the treatment of pancreatic cancer. Clin Cancer Res 14:5646-5648

Smith J, Tho LM, Xu N, Gillespie DA (2010) The ATM-Chk2 and ATR-Chk1 pathways in DNA damage signaling and cancer. Adv Cancer Res 108:73-112

Suzuki T, Kiyokawa N, Taguchi T, Sekino T, Katagiri YU, Fujimoto J (2001) CD24 induces apoptosis in human B cells via the glycolipid-enriched membrane domains/raftsmediated signaling system. J Immunol 166:5567-5577

van der Gun BT, Melchers LJ, Ruiters MH, de Leij LF, McLaughlin PM, Rots MG (2010) EpCAM in carcinogenesis: the good, the bad or the ugly. Carcinogenesis 31 : 1913-1921

Vasania VS, Prasad P, Gill RK, Mehta A, Viswanathan C, Sarang S, Majumdar AS (2011) Molecular and cellular characterization of expanded and cryopreserved human limbal epithelial stem cells reveal unique immunological properties. Exp Eye Res 92:47-56

Ware CB, Nelson AM, Blau CA (2005) Controlled-rate freezing of human ES cells. Biotechniques 38:879-883

Woods EJ, Benson JD, Agca Y, Critser JK (2004) Fundamental cryobiology of reproductive cells and tissues. Cryobiology 48:146-156

Zhang M, Rosen JM (2006) Stem cells in the etiology and treatment of cancer. Curr Opin Genet Dev 16:60-64

Zocchi E, Usai C, Guida L, Franco L, Bruzzone S, Passalacqua M, De Flora A (1999) Ligand-induced internalization of $\mathrm{CD} 38$ results in intracellular $\mathrm{Ca} 2+$ mobilization: role of $\mathrm{NAD}+$ transport across cell membranes. FASEB J 13:273-283 